\title{
NON-TIMBER FOREST PRODUCTS (NTFPS) IN THE SAGARMATHA NATIONAL PARK, NEPAL HIMALAYA
}

\author{
Krishna R. Bhattarai*, Bharat B. Shrestha** and Hari D. Lekhak** \\ *Birendra Sainik Mahavidiayalaya, Bhaktapur, Nepal. \\ **Central Department of Botany, T.U., Kirtipur, Kathmandu, Nepal.
}

\begin{abstract}
Present study was conducted to explore and document the non-timber forest products (NTFPs) in the Sagarmatha National Park (SNP) Nepal Himalaya, and to assess their conservation status. The field data was collected from June 21 to July 15, 2004. Primary information of NTFPs was based on Participatory Rural Appraisal (PRA) which included field observation, interviews and focus group discussion. Altogether 103 species of NTFPs belonging to 40 families and 74 genera, used for food, firewood, fodder, buildings construction, incense, and medicines were recorded from the study area. Out of them, 21 species were found to be dominant, 29 species abundant, 35 species common, 14 not so common and 4 species rare. Furthermore, 17 species of lichens belonging to six families and eight genera were also recorded. Impact on the vegetation was mostly due to the disturbance by tourism, animal grazing, building of houses, fuel wood and timber collection. Ecological study of the representative NTFPs showed that number of medicinal plants was comparatively low in all the areas investigated. Arenaria sp., Rhododendron sp., Juniperus sp., Abies spectabilis., Pinus wallichiana., Betula utilis, Lyonia ovalifolia., Arundinaria sp., Zanthoxylum armatum., Dactylorhiza hatagirea, Neopicrorhiza scrophulariiflora, Ferns, Mushrooms, etc. have been found to be directly or indirectly affected by tourists and guides/porters.
\end{abstract}

Key words: Sagarmatha; NTFPs; Conservation status; Impact; Tourism.

\section{INTRODUCTION}

Indigenous societies in Nepal have been utilizing a large number of plant resources to meet their basic needs such as food, medicine, fiber, tannin, timber, aroma, ornament, etc and large number of Nepalese are relying on plants and animal resources of forest, wetlands and community land for their subsistence (Dangol, 2002; Rokaya, 2002). Non timber Forest Products (NTFPs) include all biological materials and different services rendered by forest land, for example, medicinal plants, fiber-yielding, dye-yielding, fatty-oil bearing plants, wild edible plants, thatching grasses, rattan, resins, pesticides, animal bedding, veterinary medicines, green manure, ornamental plants, cosmetics, gums, honey, wildlife products etc (MFSC, 1993). In Nepal, NTFPs offer large opportunities in terms of products, employment, and income generation but, as with other renewable resources, attempts to utilize these resources carry with them the risk of rapid depletion (Tewari and Campbell, 1996). NTFPs have been recently recognized as a major forest product, but for rural community, these products have always been crucial life support system (Chandrashekharan, 1998; Giri et al., 2001).

In recent years, the collection of NTFPs has increased due to lack of local control over the resources (Shrestha et al., 1998) and rural poverty. Documentation of NTFPs and their traditional uses are very essential, which might help the community in improving their economic condition. This can also help in sustainable management of NTFPs and conservation of indigenous knowledge for their uses.

Among all categories of NTFPs medicinal and aromatic plants (MAPs) play vital role in Nepalese livelihood, health, and socio-economic prospects. The importance of NTFPs in terms of high value but low volume and weight increases as the altitude increases (Kanel, 2000). Therefore, high mountains and hills are important for NTFPs, mainly MAPs. The Sagarmatha National Park, Nepal (elevation 2,845 m to 8,848 $\mathrm{m}$ asl) constitutes about $69 \%$ of barren land above 5,000 m, $28 \%$ grazing land and nearly 3\% of forest. Dactylorhiza hatagirea, Juniperus indica, Nardostachys grandiflora, Valeriana wallichii, Hippophae tibetana, Taxus wallichiana and Betula utilis, various types of fungi, mosses, and lichens are good sources of NTFPs in this area. UNESCO listed the SNP as a World Heritage Site in 1979 for its superb natural characteristics. Now a day, the economy of local Sherpa community is becoming increasingly dependent on tourism rather than agriculture, livestock herding and trade in the

Author for Correspondence: Krishna R. Bhattarai, Birendra Sainik Mahavidiayalaya, Bhaktapur. E-mail: krbhattarai@gmail.com. 
area. The indigenous knowledge regarding the use of NTFPs in the Sagarmatha National Park is since the time immemorial by local people and amchis. Tourism has grown in the Sagarmatha National Park since 1964 AD and 21,960 tourists visited the area in the fiscal year 2003-2004 (WWF, 2004). Bjoneness (1983) feared that tourist has caused extensive deforestation. At higher altitudes, Juniper scrub, which requires 60 or more years to mature to the size of $35 \mathrm{~cm} \mathrm{CBH}$ above the ground, are cut and their root extracted.

\section{MATERIALS AND METHODS}

The fieldwork was conducted in the Sagarmatha (Everest) National Park, Nepal from June 21 to July 15, 2004. The fieldwork comprised of two approaches, survey techniques and inventory techniques (Martin, 1995; Rastogi et al., 1998; Cunningham, 2001). For the collection of the field data participatory methods such as Rapid Rural Appraisal (RRA) and Participatory Rural Appraisal (PRA), were employed. PRA and informal interviews were conducted with Amchis, Sherpa, local residents and school teachers.

For sampling of NTFPs, seven study sites at Phortse (three locations), Somare, Pheriche (two locations), Zongla, Gokyo, Dole and Thame were selected along the trekking route from map1. In each of these habitats, transects of $100 \mathrm{~m}$ long were laid down. In each of these transects series of square quadrats (1 m x $1 \mathrm{~m}$ for herbs and $5 \mathrm{~m}$ x $5 \mathrm{~m}$ for shrubs) were made at an interval of 5 to $10 \mathrm{~m}$. The number of quadrats laid in these habitats ranged from nine to eighteen at different sites. In each of these quadrats all the individuals of encountered medicinal plant species were counted. From these data, frequency and density of the representative medicinal plants were determined (Zobel et al., 1987; Dallmeir, 1992). The abundance criteria used by Ghimire et al. (2000) in Dolpo was followed. The assigned five criteria were: dominant, abundant, common, not so common and rare.

The voucher specimens were prepared following standard techniques described by Martin (1995). They were identified using standard literatures (Hara et. al., 1978, 1982; Hara and Williams, 1979; Polunin and Stainton, 1984; Stainton, 1988; Zheng-yi and Raven, 1994, Press et al., 2000; Lama et al., 2001; Bista et al.2001) and by comparing with the specimens deposited at Tribhuvan University Central Herbarium (TUCH). The plant specimens collected were not only from those lying within the quadrats but also from along the walking route while visiting the different sites. All the lichens specimens were collected while walking and not from quadrats.

\section{RESULTS AND DISCUSSION}

NTFPs and their use in SNP: Most of the plant species growing in SNP area are used as NTFPs in one or more ways. A total of 103 species and three varieties of plants belonging to 40 families and 74 genera have been recorded including the detail information about uses and availability. Out of 40 families representing from the study area the largest families were found to be are Scrophulariaceae (15 species: 2 genera), Rosaceae (14 species: 6 genera), Compositae (10 species: 8 genera) and Ericaceae (7 species: 4 genera) (fig.1). The largest genera are Potentilla with 8 species, Pedicularis with 5 species and Rhododendron with 4 species. Some of the representative plants with their quantitative characteristics are shown in Table 1 . Out of 103 NTFPs, 21 species were found to be dominant, 29 species abundant, 35 species common, 14 not so common and 4 species as rare (Fig 2). In addition to the vascular plants, lichens were also collected along the walking route while visiting the different sites. The recorded lichens belonged to six families, eight genera and seventeen species (Table 2). None of the lichen recorded were found to be used by the local people in daily life in the study area. The species of lichens found in SNP were also recorded by Baniya and Gupta (2002) from Makalu-Barun National Park and Buffer zone area, which is also the high altitude habitat.

The distribution of representative NTFPs in the present study area was comparatively low in number but high frequency. The population characteristics showed that among the collected shrub samples, Rhododendron species had the highest frequency (F) and density (D) followed by Juniperus, Cassiope, Ephedra, etc. whereas, among herbs, Potentilla, Pedicularis etc. had highest frequency and density. The number of NTFPs species declined with increasing elevation,

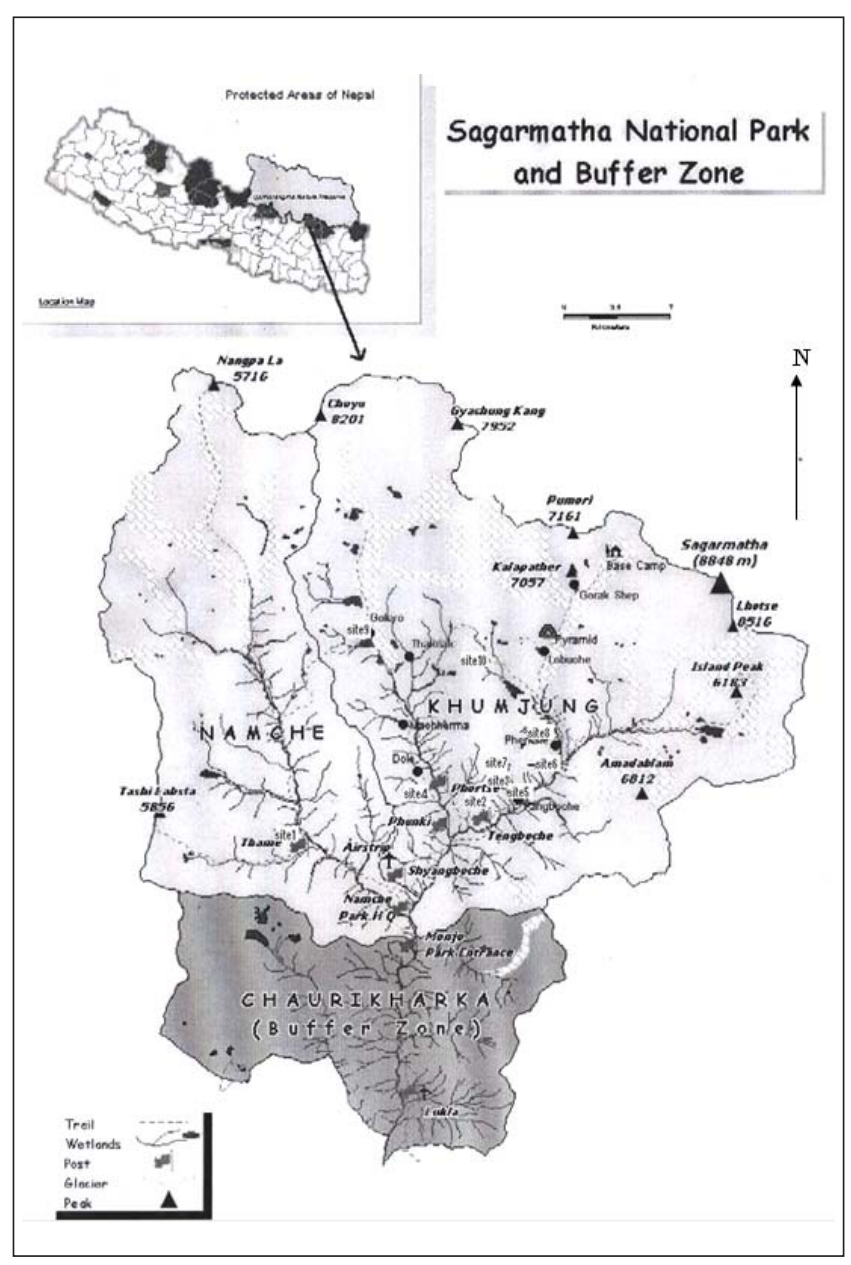


but aspects and moisture availability also affected this trend. None of the NTFPs recorded in the area in this study are found to be endemic to east Nepal. According to amchi of Namche (Dr. Sherab Tenzin Berma), there were more than 200 species of medicinal plants, out of which about 35 types were used by himself for the treatment of high altitude sickness (HAS), gout, gastritis, common cold, sinusitis, headache, typhoid, jaundice, and gastro-intestinal diseases like diarrhoea, ascariasis, etc. The volume of any NTFPs involved in trade from SNP area is not well quantified. Although the collection of herbs from national park area is legally forbidden, however, many people sneak in the park area and collect the resources therein. According to the local people most of outsiders interested in short term gain freely enter the area and smuggle the medicinal herbs, particularly Jatamansi (Nardostachys grandiflora) and Panchaunle (Dactylorhiza hatagirea).

\section{Visitors Impacted Plant species:}

Although tourism contributes significantly to earn foreign currency and providing job opportunities to local people, the visitors exert tremendous pressure on the slow growing scarce forest resources of SNP (WWF, 2004). The visitors are of two types, that is, tourists and guides/porters, and they cause different types of impact on vegetation. Tourists have caused indirect impact on vegetation because many of them stay at hotels that use fire- wood for cooking and space heating. Similarly, many lodges are constructed with timber that was harvested from sub alpine forests. For this purpose people use plants like Abies, Juniperus, Lyonia, Quercus, Pinus, etc. According to the data available in SNP office, Namche, for construction of houses and monasteries at Namche and Khumjung 77 Pine trees were cut in 2003AD. Similarly form buffer zone area about 120 trees cut annually. Similarly to make prayers flag by Buddhists about 80-90 pine trees were cut annually (Ahkikari, 2004). The porters cause mainly direct impact on vegetation as most of them cook food themselves by collecting vegetables and fire wood from the forest. According to SNP office Namche, 22,329 porters have entered in Khumbu area in 2003AD. In tourist season their flow in park area is about 120 to 150 per day. They collect fire wood from Pieris formosa, Abies, Betula, Lyonia, Rhododendron etc. and use Mushroom, Fern, Bambooshoots, Timur, Jimbu etc. as vegetables and condiments. Almost all of the above mentioned plants have religious significance as well as use in other purposes by the local people. Many visitors, especially porters have been involved in the illegal collection of valuable plants like Dactylorhiza hatagirea (Paanch aunle), Neopicrorhiza scrophulariiflora (Kutki), Rhododendron anthopogon (Sunpati), edible mushrooms etc. from forests.

NTFPs in SNP have been disturbed by various agents like tourists, cattle grazing, local people and migrants. Bhuju and Rana (2002) reported the degradation of NTFPs by haphazard use of plants by tourists and local people for fuel wood and timber in SNP. Similar findings also expressed by Kunwar (2002) in Northern part of west Nepal and mentioned that the high altitude NTFPs were generally disturbed due to animal grazing, building of houses, recreational activities and deforestation, forest fires and cultivation. Study of the representative medicinal plants showed that number of medicinal plants were low in number in all the areas (Table 1). The present results are similar to findings of Rokaya (2002) in high altitude NTFPs of Dho-Tarap area, upper Dolpo, in which he reported that the area nearby the river was rich in NTFPs whereas dry-grass land habitat or scrubby habitats were relatively poor in NTFPs.

The main physical impact of trekking and mountaineering expeditions was on park forests. The depletion of high altitude Juniper forest was the most prominent damage caused by tourists groups. The cushion-form of perennials of several genera including Stellaria, Saxifraga and Arenaria of the alpine zone are also being threatened. They are easily dislodged and burn almost as dung. Destruction by burning of such very slow growing plants lead to surface instability and soil erosion. Though trekkers and mountaineers are not allowed to use any sort of vegetation for fuel purpose but it was found that local people collect such cushion plants and sell to trekkers for Rs. 500-600 per pack (one doko, about 20 Kg). Use of Arenaria for camp fire was noted near Thagnak because uprooted signs on land were observed widely around camping sites. Similarly, cut marks of branch on Junipers were observed near Lobuche, Zongla and Gokyo. Information was also obtained that some people have been involved in illegal supply of cut branches of Rhododendron anthopogon, Juniperus indica, and cushion plants such as Arenaria to

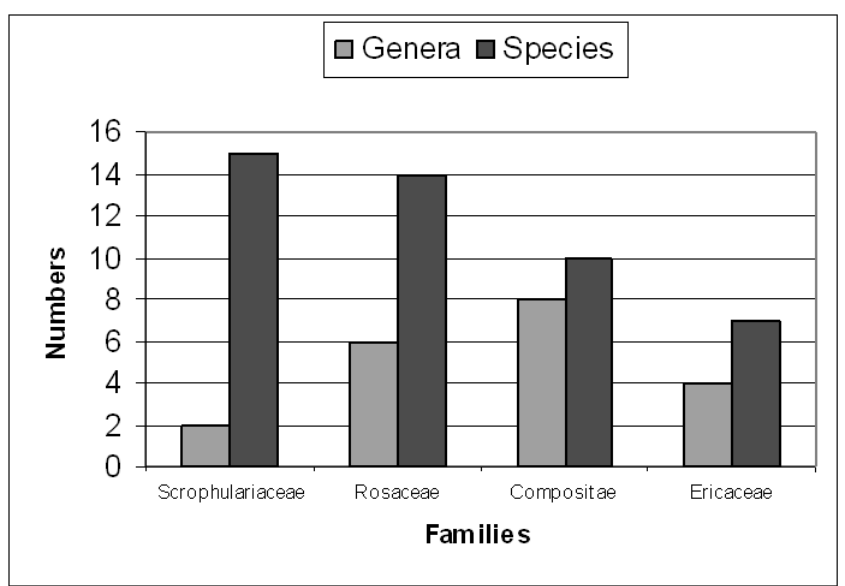

Fig.1: Representative families with no .of genera and species

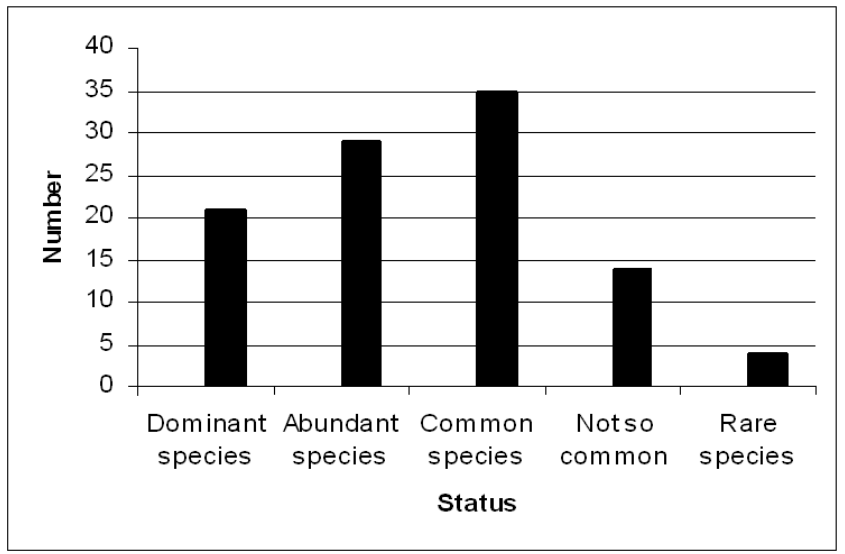

Fig. 2: Status of NTFPs in SNP 
Table 1: Frequency (\%) and density $\left(\mathrm{ha}^{-1}\right)$ of plant species of non timber forest products (NTFPs) at different elevation ranges.

\begin{tabular}{|c|c|c|c|c|c|c|c|c|c|}
\hline \multirow{4}{*}{$\begin{array}{l}\mathrm{S} \\
\mathrm{N}\end{array}$} & \multirow{3}{*}{\multicolumn{2}{|c|}{ Plant species }} & \multicolumn{7}{|c|}{ Elevation range $(\mathrm{m})$} \\
\hline & & & \multicolumn{2}{|c|}{$3500-4000$} & \multicolumn{2}{|c|}{$4000-4500$} & \multicolumn{2}{|c|}{$4500-5000$} & \multirow{3}{*}{ Uses } \\
\hline & & & \multirow[t]{2}{*}{$\mathrm{F}(\%)$} & \multirow[t]{2}{*}{$\mathrm{D}\left(\mathrm{ha}^{-1}\right)$} & \multirow[t]{2}{*}{$\mathrm{F}(\%)$} & \multirow[t]{2}{*}{$\mathrm{D}\left(\mathrm{ha}^{-1}\right)$} & \multirow[t]{2}{*}{$\mathrm{F}(\%)$} & \multirow[t]{2}{*}{$\mathrm{D}\left(\mathrm{ha}^{-1}\right)$} & \\
\hline & Shrubs & $\begin{array}{l}\text { Collection } \\
\text { no. }\end{array}$ & & & & & & & \\
\hline 1 & Berberis mucrifolia Ahrendt & SNP 25 & - & - & 30 & 86 & - & - & It is used in cough. Fruits are edible. \\
\hline 2 & $\begin{array}{l}\text { Cassiope fastigiata (Wall) } \\
\text { D.Don. }\end{array}$ & SNP 18 A & 28 & 258 & 16 & 104 & 26 & 309 & $\begin{array}{l}\text { Braches are used as incense. Used in } \\
\text { holes to store (pack) potatoes and on the } \\
\text { roofs. }\end{array}$ \\
\hline 3 & $\begin{array}{l}\text { Cotoneaster microphyllus Wall. } \\
\text { ex Lind. }\end{array}$ & SNP 7 & 33 & 52 & 7 & 7 & - & - & $\begin{array}{l}\text { Fruits are used in rheumatism, menstrual } \\
\text { disorder and lymph problems }\end{array}$ \\
\hline 4 & $\begin{array}{l}\text { Ephedra gerardiana Wall ex } \\
\text { Stapf }\end{array}$ & $\begin{array}{l}\text { SNP 13; } \\
77 ; 82 ; 85\end{array}$ & - & - & 19 & 141 & 48 & 631 & $\begin{array}{l}\text { Leaves and fruits are used to check } \\
\text { bleeding and for blood purification and } \\
\text { cough. }\end{array}$ \\
\hline 5 & Juniperus indica Bert. & SNP 24 & 38 & 86 & 20 & 23 & 11 & 33 & $\begin{array}{l}\text { Leaves and fruits are used in lung and } \\
\text { kidney problems Leaves are used for } \\
\text { incense, stem as fire-wood. }\end{array}$ \\
\hline 6 & $\begin{array}{l}\text { Juniperus recurva Buch.- } \\
\text { Ham.ex D.Don }\end{array}$ & SNP 23 & 28 & 42 & 9 & 4 & - & - & $\begin{array}{l}\text { Leaves and fruits are used as diuretic in } \\
\text { kidney problem, skin diseases. Leaves } \\
\text { and the branches are used for incense, } \\
\text { fire-wood. }\end{array}$ \\
\hline 7 & $\begin{array}{l}\text { Lonicera obovata Royle ex } \\
\text { Hook.f. \&Thoms. }\end{array}$ & SNP 71 & - & - & 9 & 40 & - & - & $\begin{array}{l}\text { Wood is used in eye problem, cough, } \\
\text { gastritis. }\end{array}$ \\
\hline 8 & $\begin{array}{l}\text { Rhododendron campylocarpum } \\
\text { Hook.f. }\end{array}$ & $\begin{array}{l}\text { SNP 15; } \\
91\end{array}$ & - & - & 7 & 15 & - & - & Used as fire- wood \\
\hline 9 & $\begin{array}{l}\text { Rhododendron lepidotum } \\
\text { Wallich ex G. Don }\end{array}$ & SNP 5; 26 & 83 & 847 & 30 & 167 & - & - & $\begin{array}{l}\text { Leaves and flowers are taken for blood } \\
\text { purification, bile disorder, lungs disorder, } \\
\text { pain, cold, as appetizer and digestive., } \\
\text { plant is used as fire-wood. }\end{array}$ \\
\hline 10 & $\begin{array}{l}\text { Rhododendron anthopogon } \\
\text { D.Don }\end{array}$ & $\begin{array}{l}\text { SNP 28; } \\
73\end{array}$ & - & - & 31 & 163 & 48 & 583 & $\begin{array}{l}\text { Young and fresh flowers are used in } \\
\text { making herbal tea which is used in liver } \\
\text { disorders, allergy and vomiting. Leaves } \\
\text { and flowers are used in incense with other } \\
\text { herbs }\end{array}$ \\
\hline 11 & Rhododendron setosum D.Don & SNP 27 & - & - & 30 & 146 & 26 & 561 & Used as fire wood and incense. \\
\hline 12 & Rosa sericea Lindley & SNP 4; 29 & - & - & 7 & 5 & - & - & $\begin{array}{l}\text { Flowers and fruits are used in fever,. } \\
\text { Fruits are also used in jaundice. Flowers } \\
\text { are used to make herbal tea }\end{array}$ \\
\hline \multirow[t]{2}{*}{13} & Salix sclerophylla Andresson & SNP 16 & - & - & 10 & 8 & - & - & $\begin{array}{l}\text { Flowers, fruits and barks are used as } \\
\text { diuretic, and in cough, used as fire wood. }\end{array}$ \\
\hline & \multicolumn{9}{|l|}{ Herbs } \\
\hline 1 & $\begin{array}{l}\text { Anaphalis monocephala (DC.) } \\
\text { Airy Shaw }\end{array}$ & SNP 42 & - & - & 9 & 28 & - & - & $\begin{array}{l}\text { Leaf, Flower, Stem are used in digestion, } \\
\text { antidote of poison, blood clotting, } \\
\text { swelling due to coldness. }\end{array}$ \\
\hline 2 & Anemone obtusiloba D.Don & $\begin{array}{l}\text { SNP 56; } \\
68 ; 115\end{array}$ & - & - & 7 & 20 & - & - & $\begin{array}{l}\text { Seeds, flowers and leaves are used in } \\
\text { digestion, Plant paste is given to treat } \\
\text { cough and fever. }\end{array}$ \\
\hline 3 & $\begin{array}{l}\text { Arenaria polytrichoides } \\
\text { Edgew. ex Edgew.\& Hook.f. }\end{array}$ & SNP 72 & - & - & 2 & 2 & 17 & 277 & Used as fodder and fire-wood in heaters \\
\hline 4 & Astragalus donianus DC. & SNP 105 & 14 & 26 & - & - & - & - & $\begin{array}{l}\text { Whole plant is used in kidney problem, } \\
\text { weakness, blood and menstrual disorders. }\end{array}$ \\
\hline 5 & Cypripedium himalaicum Rolfe & SNP 39 & - & - & 9 & 26 & - & - & $\begin{array}{l}\text { Animals while grazing in the open land } \\
\text { consume it. }\end{array}$ \\
\hline 6 & Elsholtzia densa Benth. & SNP 104 & 17 & 15 & - & - & - & - & $\begin{array}{l}\text { Leaves and fruits are used to prevent } \\
\text { infections on cuts and wounds }\end{array}$ \\
\hline 7 & Fern & & - & - & 8 & 100 & - & - & $\begin{array}{l}\text { Fodder, used as vegetable, and to make } \\
\text { pickle. }\end{array}$ \\
\hline 8 & $\begin{array}{l}\text { Fragaria nubicola Lind. ex } \\
\text { Lacaita }\end{array}$ & SNP 98 & 361 & 121 & - & - & - & - & $\begin{array}{l}\text { Leaves, flowers and fruits are used in } \\
\text { kidney problem, checks the high blood } \\
\text { flow during the menstruation. Fruits } \\
\text { edible }\end{array}$ \\
\hline 9 & Herminium sp. & SNP 40 & - & - & 3 & 2 & - & - & Used as fodder. \\
\hline 10 & Lilium nanum Klotzsch & $\begin{array}{l}\text { SNP 45; } \\
89 ; 101\end{array}$ & - & - & 10 & 56 & - & - & Bulbs are used as tonic. \\
\hline 11 & $\begin{array}{l}\text { Meconopsis horridula Hook.f. } \\
\text { \& Thomson }\end{array}$ & $\begin{array}{l}\text { SNP 61; } \\
67\end{array}$ & - & - & 3 & 11 & - & - & $\begin{array}{l}\text { Leaves, flowers and fruits are used in } \\
\text { headache, heart problem, blood disorder, } \\
\text { bone fracture, back pain, cold, sinusitis, } \\
\text { bile disorder, skin problems and wounds. }\end{array}$ \\
\hline 12 & Meconopsis paniculata Prain & SNP 00 & - & - & 2 & 15 & - & - & Used in headache \\
\hline 13 & $\begin{array}{l}\text { Nannoglottis hookeri } \\
\text { (C.B.Clarke ex Hook.f.) Kitam }\end{array}$ & SNP 41 & - & |- & 3 & 27 & - & - & $\begin{array}{l}\text { Animals while grazing in the open land } \\
\text { consume it. }\end{array}$ \\
\hline
\end{tabular}




\begin{tabular}{|c|c|c|c|c|c|c|c|c|c|}
\hline \multirow{3}{*}{$\begin{array}{l}\mathbf{S} \\
\mathbf{N}\end{array}$} & \multirow{3}{*}{\multicolumn{2}{|c|}{ Plant species }} & \multicolumn{7}{|c|}{ Elevation range (m) } \\
\hline & & & \multicolumn{2}{|c|}{$3500-4000$} & \multicolumn{2}{|c|}{$4000-4500$} & \multicolumn{2}{|c|}{$4500-5000$} & \multirow[b]{2}{*}{ Uses } \\
\hline & & & $\mathrm{F}(\%)$ & $\mathrm{D}\left(\mathrm{ha}^{-1}\right)$ & $\mathrm{F}(\%)$ & $\mathrm{D}\left(\mathrm{ha}^{-1}\right)$ & $\mathrm{F}(\%)$ & $\mathrm{D}\left(\mathrm{ha}^{-1}\right)$ & \\
\hline 14 & $\begin{array}{l}\text { Oxytropis lapponica (Wahlenb.) } \\
\text { Gay }\end{array}$ & $\begin{array}{l}\text { SNP 51; } \\
60\end{array}$ & - & - & 13 & 48 & - & - & $\begin{array}{l}\text { Animals while grazing in the open } \\
\text { land consume it. }\end{array}$ \\
\hline 15 & Pedicularis oederi Vahl & $\begin{array}{l}\text { SNP, 65; } \\
79\end{array}$ & - & - & 11 & 35 & 11 & 229 & $\begin{array}{l}\text { Animals consume it while grazing in } \\
\text { the open land }\end{array}$ \\
\hline 16 & $\begin{array}{l}\text { Pedicularis rhinanthoides } \\
\text { Schrenk }\end{array}$ & SNP 47 & - & - & 12 & 42 & - & - & $\begin{array}{l}\text { Whole plant is used in cough, sore } \\
\text { throat, liver and lymph disorder }\end{array}$ \\
\hline 17 & Pedicularis siphonantha D.Don & $\begin{array}{l}\text { SNP62; } \\
\text { 83 A }\end{array}$ & - & - & - & - & 20 & 114 & $\begin{array}{l}\text { Whole plant is used in fever, bile } \\
\text { disorder, lymph, disorder }\end{array}$ \\
\hline 18 & $\begin{array}{l}\text { Phlomis rotata Benth. ex } \\
\text { Hook.f. }\end{array}$ & SNP 59 & - & - & - & - & 15 & 111 & $\begin{array}{l}\text { Flowers and fruits are used in heart } \\
\text { fever, }\end{array}$ \\
\hline 19 & Potentilla anserina $\mathrm{L}$. & $\begin{array}{l}\text { SNP 22; } \\
111\end{array}$ & 31 & 3161 & - & - & - & - & $\begin{array}{l}\text { Whole plant is used in diarrhea, } \\
\text { stomach problems. }\end{array}$ \\
\hline 20 & Potentilla peduncularis D.Don & SNP 90 & - & - & 10 & 300 & - & - & $\begin{array}{l}\text { Whole plant is used as appetizer and } \\
\text { in stomach problem. }\end{array}$ \\
\hline 21 & $\begin{array}{l}\text { Potentilla plurijuga Hand.- } \\
\text { Mazz. }\end{array}$ & SNP 106 & 17 & 97 & - & - & - & - & $\begin{array}{l}\text { Whole plant is used in gastritis and } \\
\text { as appetizer. }\end{array}$ \\
\hline 22 & Potentilla sp. & SNP 21 & 42 & 481 & 2 & 22 & 32 & 481 & $\begin{array}{l}\text { Whole plant is used in gastritis and } \\
\text { as appetizer. }\end{array}$ \\
\hline 23 & Primula denticulata Smith & $\begin{array}{l}\text { SNP 11; } \\
30\end{array}$ & - & - & - & - & 4 & 14 & $\begin{array}{l}\text { Flowers are used in stomach } \\
\text { disorder. }\end{array}$ \\
\hline 24 & Primula sikkimensis Hook.f. & SNP 29 & - & - & 17 & 103 & - & - & $\begin{array}{l}\text { Flowers are used in intestinal } \\
\text { problem, fever, rheumatic fever, } \\
\text { lungs and heart fever, diarrhea. }\end{array}$ \\
\hline 25 & Primula wollastonii Balf.f & SNP 107 & 17 & 50 & - & - & - & -- & $\begin{array}{l}\text { Flowers are used in intestinal } \\
\text { problem, fever, rheumatic fever, } \\
\text { lungs and heart fever. }\end{array}$ \\
\hline 26 & Rheum spiciforme Royle & SNP 69 & 8 & 17 & 6 & 37 & - & - & $\begin{array}{l}\text { Roots and petioles are used as } \\
\text { diuretic, in gastritis, stomachache } \\
\text { from cold, bile problem. }\end{array}$ \\
\hline 27 & Saxifraga roylei Harry Smith & SNP 66 & - & - & 8 & 17 & - & - & $\begin{array}{l}\text { Leaves and flowers are used in lung } \\
\text { diseases, cough. }\end{array}$ \\
\hline 28 & Unidentified-140(Gramineae) & SNP 140 & - & - & 9 & 35 & - & - & Used as fodder \\
\hline 29 & $\begin{array}{l}\text { Waldheimia nivea ( Hook. } \\
\text { f.\&Thoms.ex C.B. Clarke) } \\
\text { Regel }\end{array}$ & SNP 84 & - & - & - & - & 15 & 114 & $\begin{array}{l}\text { Animals while grazing in the open } \\
\text { land consume it. }\end{array}$ \\
\hline
\end{tabular}

Table 2: Lichens of Sagarmatha National Park

\begin{tabular}{|c|c|c|c|c|}
\hline S.N. & Botanical name & Tag No. & Family & Place of collection \\
\hline & Rock lichens & & & \\
\hline 1 & $\begin{array}{l}\text { Cladonia coccifera } \\
\text { (L.)Willd. }\end{array}$ & L 1 & Cladoniaceae & Pangboche;3800m \\
\hline 2 & Cladonia ramulosa & L2 & Cladoniaceae & Pangboche;3820m \\
\hline \multirow[t]{2}{*}{3} & Cladonia sp. & L3 & Cladoniaceae & Pangboche;3820m \\
\hline & Lichens on tree & & & \\
\hline 4 & Cladonia sp. & L 5 & Cladoniaceae & Way to Chola;5160m \\
\hline 5 & Cladonia sp. & L 6 & Cladoniaceae & Pangboche; 3830m \\
\hline 6 & $\begin{array}{l}\text { Heterodermia } \\
\text { leucomela (L.) Poelt }\end{array}$ & L 7 & Physciaceae & Pangboche;3900m \\
\hline 7 & Heterodermia sp & L 8 & Physicaceae & Pangboche;3850m \\
\hline \multirow[t]{2}{*}{8} & Heterodermia sp & L 9 & Physicaceae & Pangboche 3820m \\
\hline & On land/rock & & & \\
\hline 9 & Heterodermia sp. & L 11 & Physicaceae & Pangboche $3820 \mathrm{~m}$ \\
\hline 10 & $\begin{array}{l}\text { Heterodermia } \\
\text { speciosa (Wulf.)Trev. }\end{array}$ & L 12 & Physicaceae & Pangboche; 3840m \\
\hline 11 & $\begin{array}{l}\text { Lobaria retigera } \\
\text { (Bory) trev. }\end{array}$ & L 13 & Usneaceae & Pangboche; 3800m \\
\hline \multirow[t]{2}{*}{12} & Pyxine sp. & 1-03 SNP & physciaceae & Pangboche;3820m \\
\hline & On tree /land & & & \\
\hline 13 & Stereocaulon sp. & 2-03 SNP & stereocaulaceae & Pangboche;3800m \\
\hline 14 & Sticta sp. & 1-01 SNP & Stictaceae & Way to Chola;5120m \\
\hline 15 & $\begin{array}{l}\text { Usnea longissima } \\
\text { Ach. }\end{array}$ & L 14 & Usneaceae & Pangboche;3820m \\
\hline 16 & Usnea sp. & 2-01 SNP & Usneaceae & Near Dole;4200m \\
\hline 17 & Xanthoria sp & L 15 & Teleschistaceae & Near Dole;4200m \\
\hline
\end{tabular}

base camp of Sagarmatha. Collection of yak-dung from forest and pasture were also observed during the study. These are used for room heating in hotels and lodges. Such activities causes impact on nutrient supply and regeneration of plants.

Large area of the park is used for grazing, both during winter and summer. Although, cattle graze mostly in open areas, they move through the forest searching any available food and destroying seedlings and saplings by trampling and browsing so that grass species invade suppressing tree seedling growth and development. Grazing in forest areas was found in Phortse, Somare and Dole and grazing in open land i.e. scrubs was found in Pheriche, Lobuche, Gokyo, Thangnak and Phanga. The changing trend in animal types (cross-breeds) appears to be important for park management. The cross-breed animal owners occupied high altitude pastures in summer for much shorter periods than yak and nak owners. This activity was disregarded for the traditional mechanisms that insured better seasonal migration of livestock. There was high pressure on low altitude pastures and forest that leads to increased proportion of grazing resistant vegetation, reduced vegetation cover, increased soil compaction, terrace formation and trail incision near villages (Brower, 1987).

Forest within the park has been used traditionally for the collections of forest products especially fire-wood. Rise in tourism and mountaineering has increased the use of fire wood. It was estimated that each household at Khumbu region 
used $>43 \mathrm{~kg}$ fire-wood each day for cooking and room heating (Adhikari, 2004). Similarly, the increasing number of hotels and lodges and increasing numbers of guides/ porters, carpenters, masons etc. from neighboring districts has increased the use of timber, fire- wood and other NTFPs. Recently, the park authority has allowed to collect dead plants only in December and May every year for fifteen days but it was found that local people were often engaged in felling the live Pine and Juniper trees round the year in high altitude areas such as Lubuche, Gokyo etc. People also collect Arundinaria, Betula utilis, Pinus and Juniperus poles to make prayer flags (Daja and Chhodar).

In addition to fire- wood, people also collect large amount of leaf-litter from both coniferous and broad leaved forests and are found to use in toilets and as animal bedding at lower storey of houses. When it partly decomposed, the litter was used as compost in agricultural fields. The collection of leaf litter is detrimental to forest growth, survival and regeneration of vegetation (Garratt, 1981).

\section{CONCLUSION}

The present study indicates that the SNP area is also a good potential site for NTFPs and many agencies are involved for their conservation but the status is gradually degrading mainly by over exploitation, inadequate awareness for conservation, illegal harvesting by visitors and by tourism related activities. Thus the conservation of biodiversity and its sustainable utilization has therefore become a collective concern of local people, government agencies, NGOs, INGOs and other concerned authorities. Present study is helpful fur further study so a detail study to assess NTFPs should be conducted.

\section{ACKNOWLEDGEMENTS}

Financial support from Tourism for Rural Poverty Alleviation Program (TRPAP) of Department of National Park and Wildlife Conservation (DNPWC), Kathmandu is gratefully acknowledged. We are thankful to MB Rokaya for providing information about study site before field visit, B Shrestha for helping in plant collection, MR Shrestha for identification of some plants and CB Baniya for identification of lichens. We are highly indebted to local people of Sagarmatha National Park for their kind co-operation during study, and National Park authority of granting permission to work inside the park.

\section{REFERENCES}

Adhikari, P. 2004. Tourism and forest resources consumption at Khumbu. Hamro Kalpa brikchha. 14(153): 4-10 (Text: Nepali).

Baniya, C.B. and Gupta, V.N. 2002. Lichens of Annapurna conservation area and Makalu-Barun Buffer zone area. In: Vegetation and Society Their Interaction in the Himalayas. Eds: Chaudhary, R.P., Subedi, B.P., Vetaas, O.R. and Asse, T.H.

Bhuju, D.R. and Rana, P. 2000. An Appraisal of Human Impact on Vegetation in High Altitudes (Khumbu Region) of Nepal. Nepal Journal of Science and Technology. 2: 101-105.

Bista, M.S., Adhikari, M.K. and Rajbhandari, K.R. (Eds.). 2001. Flowering Plants of Nepal (Phanerogams), Ministry of Forest and Soil Conservation, Department of Plant Resources, Kathmandu, Nepal.
Bjoneness, I.M. 1983. External Economic Dependency and Changing Human Adjustment to Marginal Environment in the High Himalaya, Nepal. Mountain Resources and Development. 3: 263-272.

Brower, B.A. 1987. Livestock and Landscape: The Pastoral System of Sherpa in Sagarmatha National Park, Nepal. Ph.D. dissertation in Geography. Graduate division of the University of California, Berkeley, USA

Chandrashekharan, D. 1998. NTFPs, institutions and income generation in Nepal: Lessons from community forestry. A report submitted to ICIMOD, Kathmandu. Pp. 45.

Cunningham, A.B. 2001. Applied ethnobotany: people, wild plant use and conservation. A People and Plants Conservation Manual, Earthscan, London. P. 300.

Dallmeir, F. (Ed.). 1992. Long term monitoring of biological diversity in tropical forest area: methods for establishment and inventory of permanent plots. MAB Digest 11. UNESCO, Paris.

Dangol, D.R. 2002. Economic uses of forest plant resources in western Chitwan, Nepal. Banko Jankari. 12: 56-60.

DPR. 2001. Flowering Plants of Nepal (Phanerogams), His Majesty's Government, Ministry of Forests and Soil Conservation, Department of Plant Resources, Kathmandu, Nepal.

Garratt, K.J. 1981. Sagarmatha National Park Management Plan. Department of Lands and Survey New Zeeland and National Parks and Wildlife Conservation Office, Kathmandu, Nepal.

Ghimire, S.K., Lama, Y.C., Amchi Gurung, T.N. and Aumeeruddy-Thomas, Y. 2000. Conservation of the Plant Resources, Community Development and Training in Applied Ethnobotany at Shey Phoksundo National Park and its Buffer-zone, Dolpa. Third year. WWF Nepal Program Report Series No. 40, WWF Nepal Program.

Giri, T.K., Bhattacharya, P. and Santra, S.C. 2001. Ecology and economy of NTFPs in village life - A case study from Bankura District in West Bengal, India. Annales of Forestry. 9(1): 1-16.

Hara, H. and Willams, L.H.J. 1979. Enumeration of flowering plants of Nepal. Vol. 2. British Museum (Natural History) London.

Hara, H., Chater, A.O. and Williams, L.H. J. 1982. An Enumeration of Flowering Plants of Nepal. Vol. 3. British Museum (Natural History), London.

Hara, H., Stearn ,W.T. and Williams, L.H.J. 1978. An Enumeration of Flowering Plants of Nepal. Vol. 1. British Museum (Natural History), London.

Jain, A.K. 2000. Research in 'Regulation on collection, transit and trade of medicinal plants in India'. In: Medicinal Plants Stakeholders' Meeting. TRAFFIC-India, New Delhi, India.

Kanel, K.R. 2000. Non-Timber forest Policy Issue in Nepal. In: Community based NTFP Management: Proceedings of the Third Regional Workshop, 8-9 April, 2000. (eds. Amatya, S.M.). Institute of Forestry, Pokhara, Nepal.

Kunwar, R.M. 2002. Some Threatened Medicinal and Aromatic Plants (MAPs); Status, Trade and Management Practice in Dolpa District, Mid-western Region, Nepal. J. Nat. Hist. Mus. 21:173-186.

Lama Y. C., Ghimire, S.K. and Aumeeruddy Thomas, Y. 2001. Medicinal plants of Dolpo amchis' knowledge and conservation. People and Plants Initiatives, WWF Nepal Program, Kathmandu..

Martin, G. J. 1995. Ethnobotany: A people and plants conservation manual. Chapman and Hall.

MFSC. 1993. Focus on Jaributi. Proceedings on the NTFPs seminar.Eds: Edward, D.M. and Bowen, R.M. Forest Research and Survey Centre, Minestry of Forest and Soil Conservation, Kathmandu. 
Polunin. O, and Stainton, A. 1984. Flowers of the Himalaya. Oxford University Press, New Delhi, India.

Press, J.R., Shrestha, K.K. and Sutton, D.A. 2000. Annotated checklist of the flowering plants of Nepal. The Natural History Museum, London and Central Department of Botany, Trtbhuvan University, Kathmandu, Nepal.

Rastogi, A., Godbole, A. and Shengji, P. 1998. Applied Ethnobotany in Natural Resource Management- Traditional Home Gardens. International Centre for Integrated Mountain Development (ICIMOD), Kathmandu, Nepal.

Rokaya, M.B. 2002. Ethnoecology of Medicinal Plants in Dho-Tarap Area in Buffer Zone of Shey-Phoksundo National Park, Dolpa, Nepal. M. Sc. Thesis, Central Department of Botany, Trubhuvan University, Kathmandu.

SPCC. 2003. Annual progress report for the year 2002/2003. Sagarmatha Pollution Control Committee, Namchebazaar, Solukhumbu, Nepal
Shrestha, K.K., Ghimire, S.K., Gurung, T.N., Lama, Y.C. and Thomas, Y.A. 1998. Conservation of Plant Resources, Community Development and Training in Applied Ethnobotany at SheyPhoksundo National Park and its Buffer zone, Dolpa. World Wildlife Fund, WWF Nepal, Report series No. 33, WWF Nepal.

Stainton, A. 1988.Flowers of The Himalaya: a supplement. Oxford University Press, New Delhi, India.

Tewari, D.D. and Campbell, J.Y. 1996. Increased development of NTFPs in India: some issues and concerns. Unsylva. 187(47): 26-31.

WWF. 2004. Annual Report 2003-2004. WWF Nepal Program, Baluwatar, Kathamndu, Nepal.

Zheng-yi, W. and Ravein, P.H. (eds.). 1994. Flora of China. Science Press (Beijing) and Missouri Botanical Garden, USA.

Zobel, D.B., Jha, P.K., Behan, M.J. and Yadav, U.K.R. 1987. A Practical Manual of Ecology. Ratna Book Distributors, Kathmandu, Nepal. 